\title{
THE PLACE OF WOMEN MINISTERS IN THE MISSION OF THE METHODIST CHURCH OF SOUTHERN AFRICA
}

\section{Fanie S. Mkhwanazi}

Department of Science of Religion and Missiology, University of Pretoria

\section{Tias Kgatla}

Department of Science of Religion and Missiology, University of Pretoria kgatla@mweb.co.za

\section{ABSTRACT}

This paper proposes that the ministry of ordained women within the Methodist Church of Southern Africa (MCSA) has not fully integrated women, despite the landmark decision of the MCSA Conference of 1972 to have women ordained into the full ministry of the church. At that Methodist Conference of 1972, the Methodist Church adopted a resolution to have women ordained into the ministry of the church, and yet this has not been fully realised in the life of the MCSA. Despite the fact that women form the majority of the people who come to church on Sundays, they form a very small group within ministers' ranks.

We will investigate the challenges within the MCSA that slow down its policy on the ordination of women. The paper proposes the tools that can be used to address the challenges with regard to the full acceptance of women ministers within the MCSA. Furthermore, it investigates the organisational structure of the Women's Manyano as a means for women to protest against their exclusion from full participation in the life and leadership of the church. Although what women have learnt and practise within their own women organisation has not infiltrated into the full life of the Methodist Church, they have become a force to reckon with in the MCSA.

The paper traces the causes of the marginalisation of women within the Methodist Church to patriarchal and cultural stereotypes that are determining

\section{UNISA $\cong$}

Studia Historiae Ecclesiasticae Volume 41 | Number 2 | 2015 pp. 180-197
DOI: http://dx.doi.org/10.17159/2412-4265/2015/130 Print ISSN 1017-0499 | Online 2412-4265 (C) 2015. Studia Historiae Ecclesiasticae 
the reading and understanding of the biblical text. Human nature is a condition that needs to be checked regularly in order to remove those elements that are human-made, self-serving and limiting. Some examples of psychological and cultural elements are cited as a basis for reflection and a launch pad for women empowerment, and for the transformation of the MCSA and its policy on the ministry of ordained women.

Key words: Women's Manyano; ordination of women; empowerment; transformation; marginalisation; patriarchy; ukuthwala/girl forced marriage; emancipation

\section{Introduction}

The focus of this study is on the ecclesiological need for the inclusion of women in the Methodist Church of Southern Africa's (MCSA) ordained ministry. The training of women ministers is as important as that of their male counterparts because, without women ordained ministers, the MCSA is not complete since the largest part of the church consists of women (Holness 1990, 213-216). According to the Methodist Book of Records $(2014,3)$, the MCSA membership stands at 7.3 million, with 1059 ordained men ministers and 159 ordained women ministers. The skewed ratio of men ministers to women ministers in the church, where women are forming the overwhelming majority of the congregation, is further compounded by the fact that women are more religious than men (Holness 1990, 216). The adverse conditions in the MCSA are aggravated by religious and cultural stereotypes.

This paper traces the causes of the marginalisation of women within the Methodist Church to patriarchal and cultural stereotypes that are determining the reading and understanding of the biblical text. Human nature is a condition that needs to be checked regularly in order to remove those elements that are humanmade, self-serving and limiting (Myers 1999, 123). Some examples of psychological and cultural elements are cited as a basis for reflection and a launch pad for women empowerment, and for the transformation of the MCSA and its policy on the ministry of ordained women.

The rejection of ordained women ministers by their male counterparts, the African culture's depreciating view of women and biblical texts that support such stereotypes, lead to many women ministers leaving the church after their initial training, while others choose not to pursue further studies after their ordination because they do not see themselves receiving any recognition, despite studying further (these views were expressed by the participants of the study). Furthermore, men ministers who are in the leadership of the church do not invite ordained women ministers to come and work in their circuits in order for the women ministers to gain experience through the men ministers' mentorship, and the women do not feel welcomed in the church. 
In the majority of cases, many ordained women ministers are stationed in rural circuits where they cannot cope with challenges such as African traditional stereotypes against women in ordained ministry. The problem is worsened by a lack of solidarity between women themselves to fight against their exclusion and marginalisation. More often than not, their own internal divisions make it easy for them to become victims of male-dominated societies.

\section{African culture oppresses women}

Anthropological literature points out that almost all ethnic groups in Africa are patriarchal in structure (institutions of male rule and privilege), with relatively few exceptions. Recent research from feminist anthropologists such as Susan Kent (1998) generally supports that assessment, with a few qualifications. South African black people are mainly patriarchal in their approach to societal issues but the matrilineal group in West Africa as well as in Tanzania is not (Oduyoye 1980, 2). With more than ten male-dominated cultures (languages) in South Africa, there is no possibility of change unless planned transformation is introduced. This problem is propounded by the notorious traditional bill under discussion in South Africa, which aims to introduce traditional African courts for chiefs and their councils to adjudicate over tribal affairs (Polgreen 2012). The new bill proposes to give traditional chiefs the right to adjudicate over matters brought before them. Many women such as Sizani Ngubane of the Rural Women's Movement argue against the bill. According to Ngubane, 'rural women will find it difficult to assert their rights against these courts' (in Polgreen 2012).

As African society is essentially patriarchal, it will be difficult to find out how the reception of the roles of women can be introduced in the MCSA. Historically, patriarchy has manifested itself in most social institutions. The majority of ordained ministers are largely stationed in rural areas under the supervision of men ministers and the majority of them have no sympathy with women's quest for liberation. The discourse in all African languages portrays women not only as subordinate to men but as servants of the interests of men (Masenya 2012, 205-216). In Sesotho (one of the ethnic groups in South Africa), there is an idiomatic expression that says that a woman is like a baboon whose labour should benefit men (Rakoma 1971, 196). One of the practices found in almost all African traditional groupings of South Africa is the girl-forced marriage called ukuthwala in Zulu. Ukuthwala is the practice of abducting young girls and forcing them into marriage, often with the consent of their parents. Often parents who give their daughters in ukuthwala owe money to the men who take their daughters into the forced marriage. The marriage is seen as part of the payment for their debt (see www.africanholocaust.net accessed 10/02/2015). Another practice that demeans women is lobola. In this practice the man, or intended groom, pays a woman's family when she is taken up in marriage. The lobola price is determined by the parents without the woman's consent and the money is not used 
in her interest. Polygamy is another institution that is tailored to promote the selfish desire of men at the expense of women. These are some of the impediments against the full realisation of human rights as espoused by the Bill of Rights of South Africa.

This research aims to investigate whether the decision of the church to involve women in the full ministry of the MCSA has gone against the grain of the hegemony of patriarchy. The study presents the following questions for scrutiny:

- How could the MCSA be repositioned in its mission outreach not only to include women but also to nourish and cherish their contributions?

- Is the church transformed enough not to be paralysed by a phobia of women?

- How does the MCSA handle the question of transformation, as the question of transformation has a gender dimension to it?

- What is the gender ratio of ordained and non-ordained ministers within the MCSA leadership?

- How does this compare with men and women ratios in the country?

\section{Emancipation of women within the MCSA}

For the emancipation of women in all sectors of society, it is important that the church interprets the Bible correctly because, in many instances, people quote the Bible to justify their actions. The contention in the New Testament is the Pauline theology (Theilen 2003, 26). More and more black feminist theologians question the male interpretations of the Pauline letters, while others reject the whole hierarchical arrangement of the roles of men and women in the Bible (Hoch 1987, 242). It is clear that where there is a contest for leadership roles in society, the Bible may be used to justify the position the powerful take against those who are threatening their position. The study also serves to reveal the fears that some men may still have against women ministers, and how some men may still oppress women due to the repression they endured during the apartheid regime.

According to Hogan $(2002,3)$, oppressed people, such as women in a patriarchal society where their interests are ignored and the status quo is accepted as normal, can easily be relegated to fatalism or self-hatred. Oppressed people may easily assume that their plight is somehow ordained by nature, God or history and that there is nothing they can do about it. This seems to be the case with women members of the MCSA who attend church in larger numbers than men and, because of their vulnerability, find the space for their existence in religion (Walter 1990, 73). Walter $(1990,74)$ has observed that women outnumber men in society and also in the church. 


\section{Methodist beliefs and practices}

Core Methodist beliefs and practices affirmed by the Methodist Church Conference include the following (Minutes of Conference 1960, 156):

a. God is all knowing and all powerful, possesses infinite love and goodness and is the creator of all things.

b. God has always existed and will always continue to exist.

c. God is three persons in one - the Father, the Son and the Holy Spirit.

d. God is the master of all creation and humans are meant to live in a holy covenant with Him. Humans have broken this covenant by committing sin and can only be forgiven if they truly have faith in the love and grace of Jesus the Christ, who was crucified for the sins of all people, and who was physically resurrected to bring them the hope of eternal life.

e. The grace of God is seen by people through the work of the Holy Spirit in their lives and in the world.

f. Close adherence to the teachings of Scripture is essential to the faith because Scripture is the Word of God.

g. Christians are part of a universal church and must work with other Christians to spread the love of God.

h. Baptism is a sacrament or ceremony involving the submersion or commonly anointing of water, which cleanses the stain of original sin. It also symbolises being brought into the community of faith.

i. Communion is a sacrament in which participants eat bread and drink juice to show that they continue to take part in Christ's redeeming resurrection by symbolically taking part in His body and blood.

j. Baptism and Holy Communion are not only sacraments, but also sacrifices to God.

k. People can only be saved through faith in Jesus the Christ, not by any other acts of redemption such as good deeds.

\section{How the Methodist Church is organised}

The present MCSA remains the structure that John Wesley started in the 18th century. With his emphasis on holiness within the church as a kind of religious order (Attwell 2005, 17), Wesley established a different type of church organisation from that of the Roman Catholic Church and the Church of England. The following Classes of about 12 members, each under a Class Leader, are recognised to this day:

a. Classes fall under the leadership of a Class Leader. A Class Leader has special responsibilities of encouraging, supporting and caring for the group. 
b. The second level is a Society. A group of Classes form a Society, emphasising the fellowship of believers. The Society is led by an ordained minister to form a local church. This structure is also made up of a governing body which is called a Leaders' Meeting and it consists of lay executive officials known as Society Stewards (Attwell 2005, 17).

c. A number of societies within a particular area form what is known as a Circuit. Circuits facilitate wider fellowship, mutual financial support, shared human resources and tangible administrative organs (Attwell 2005, 17). A Superintendent Minister and the Circuit Quarterly Meeting (called Circuit Stewards) form the leadership of the Circuit (Attwell 2005, 17).

d. A wider area under the jurisdiction of the Annual District is formed by a group of Circuits.

e. Annual Districts form the Synod which is presided over by the bishop.

f. The next level of authority after the Synod is the Connexion which is governed by the Conference. The presiding bishop is at the helm of this structure.

g. The Methodist Church recognises two orders of ordained ministers. These are The Ministry of Word and Sacraments and The Ministry of Word and Service called The Order of Deacons (Attwell 2005, 17).

h. The Methodist Church has other orders of ministry open to lay members. There is the Order of Evangelists, the Order of Bible Women and the Order of Lay Preachers.

i. The Methodist Church recognises uniformed organisations such as the Wesley Guild, The Women's Manyano, the Young Women's Manyano and the Young Men's Guild. These organisations provide opportunities for ministries governed by lay people (Attwell 2005, 19).

The executive authority of the Methodist Conference is vested in the presiding bishop, the executive secretary and the Connexional units. The Methodist Connexional Office, for example, is responsible for finance and properties. The Mission Unit is responsible for the church's mission projects, the Youth Unit for the ministry to the children and the Ecumenical Affairs Unit is responsible for the church's links worldwide (Attwell 2005, 190). The Education for Ministry and Mission Unit provide training for ordained and lay ministers, while the Communications Unit is in charge of media liaison and publications (Attwell 2005, 19).

\section{Acceptance of women ministry in the MCSA}

The acceptance of women in the ministry of the MCSA started with the introduction of deaconesses. Deaconesses were introduced long ago in the MCSA, before 1963 (Oosthuizen 1990, 45). Most of them were white deaconesses and were trained 
overseas. Women who felt called to ministry were given positions as deaconesses. This practice followed the same understanding as that of the Methodist Church of England, where women who felt called could become a candidate for the ministry. They are exempt from writing the written examination to become candidates of ministry. They are only allowed to follow and fulfil the rules and regulations which apply to male candidates. Probation proceeds as it is stipulated in the rules of the church (Minutes of Methodist Conference 1964, 121). The female candidate can be on probation for another three years before she may be ordained for ministry.

Constance M. Oosthuizen was the first woman deaconess to be ordained in the ministry of Word and Sacrament in the MCSA in 1976 (Oosthuizen 1990, 45). At that time, the warden of the Deaconess Order had left South Africa for Canada. The Conference did not hesitate to appoint Oosthuizen as a successor. The following year, Oosthuizen was appointed to the Lower South Coast Circuit (in Port Shepstone) and she led an uninterrupted ministry in that Circuit from 1977 until her retirement in 1997 (Oosthuizen 1990, 45). She was followed by Dorothy Spink, who was a candidate while she was a probationer deaconess and was ordained in 1978. This Order contributed to the first black woman ordained in the South African Methodist ministry. Her name was Nikiwe Mavis Mbilini and she was ordained in 1985 (Minutes of Methodist Conference 1986). Today, this Order is being led by a man and it is still working very well for the church ministry.

As already mentioned, during the inception of the Methodist Church of England, no woman was allowed into ministry and the MCSA debated this issue for many years. It was only during a 1972 conference that women ministers were accepted into ministry. They had to be trained by the Deaconess Order first, in which Oosthuizen was accepted in 1976 (Oosthuizen 1990, 47). The second and third women to be accepted into the Order were Dorothy and Mavis Mbilini. The Mbilinis were the first black women to be ordained in the MCSA. Their ordinations saw the start of many difficulties because many women offered themselves to the ministry but were turned down. Their training at the Seminary Theological Training was the same as that of their male counterparts, but they were treated as second-class citizens in the ministry (Oosthuizen 1990, 47). For example, when the Seminary attached women to nearby churches, they were not allowed to preach but had to run Sunday Schools and participate in church choirs (information from participants in the study). The other hurdle that kept them from being accepted into ministry was because of their stationing in Circuits.

Many Circuits did not want women ministers. If they were stationed at a Circuit, members would rule that the women's heads had to be covered during services. Women's ministry was very restricted. If ministering sacraments, women were not fully accepted due to some stereotypes, which refused to allow a woman minister to perform burials (information from the participants of the study). Many questions were raised by some chauvinistic men such as whether women may administer sacraments during their menstruation. The church is clear about the ordination of 
women but the problem lies with some of the church members. This ill-treatment is experienced across the colour line. From all the women interviewed, it is evident that women are treated badly in both black and white Societies.

This led to women ministers coming together in 1995 and forming a consultation. This consultation was endorsed by the church (Minutes of Methodist Conference 1996, 102). Since then, women ministers have been meeting to enhance the ministry of women. There have been no tangible results from these meetings - not even the empowerment of women in ministry by church leadership. The only statement that was issued by this consultation was that 'we, the women ministers of the Methodist Church of Southern Africa, express our concern that the full implications of women in ministry have not been clarified' (Minutes of Methodist Conference 1996, 103). Women ministers are not adequately represented in leadership structures. Some churches such as the MCSA have ordained women ministers but the power still lies in the hands of the men clergy.

\section{Organisational church and Women's Manyano}

Women are missionary oriented as can be seen in the activities of organisations such as Women's Manyano (Women's organisation); Young Men's Guild; Local Preachers Department; Young Women's Manyano; Women's Organisation; Wesley Guild; Fellowship; and Sunday School (Brandel-Syrier 1962, 64). Yearly elections are dutifully held according to European democratic procedure, but the president or 'chairlady', once established, shows marked tendencies to stay. Group coherence is maintained by personal loyalty to the leader who acts, encourages, admonishes, advises and resolves quarrels. Her word is believed implicitly and she allots tasks to members. In the women's funeral societies, for instance, the powers of the president, who is generally the founder, are absolute. A man minister is president of all these organisations as an ordained minister, but women ministers are not welcome in some of these organisations (The Methodist Book of Order 2014, 78). Examples of these organisations are the Local Preachers Organisation and the Young Men's Guild (Methodist Year Book 1999-2000, 172). The church has made these rulings to work towards an inclusive Methodist Church and to believe that all men and women are created in the image of God (Genesis 1:26; Galatians 3:28) and that people with disabilities are allowed into Order by God so that His work may be manifested in disabled people (John 9:3). However, this is not accepted at grassroots level.

The inclusion of women in the full ministry of the Methodist Church through purposeful transformation may not be entirely possible without self-initiated women organisations, their resultant empowerment and support, their spirituality as well as their therapeutic value to many women who are excluded, marginalised and oppressed in their own church by their fellow Christians. This section focuses on the formation, skills development, management, spiritual expression, leadership development, and 
preaching and prayer discipline of women organisations within the MCSA. This discussion should provide an analysis for the skewed use of the Bible as a means of justifying one's own interest and the resultant refute of that self-acquired dominant position. Manyano organisations, in turn, gave rise to other church organisations such as the Young Women's Guild and the Men's Guild. However, the focus in this paper is on the Women's Manyano and, to a lesser extent, on the Young Women's Guild and the Men's Guild (Mkhwanazi 2002, 89).

Almost all mainline (historical) churches in South Africa have women organisations along with the mainstream denominations. Some women scholars have done intensive research into the factors that led to the formation of these women organisations (Holness 1997, 216). Scholars have also discussed the organisation's expression of spirituality (Madise 2008, 5), their leadership desires, their frustrations with male-centred churches (Hoch 1987, 242) and the cultural discourses on leadership development (Mudimeli 2011, 92-110), church discipline (Holness 1997, 200), preaching and support of one another (Walter 1990, 73-90).

There are several uncertainties and speculations about when the Manyano (known as Kopano in Sesotho which means 'the gathering') organisation started. Madise $(2008,5)$ states that the organisation was started in 1905 by Rev. Mthembu, while Preston (2007) says that it was started by Amos Burnett in the Transvaal in 1910. Attwell (in Preston 2007, 41) argues that it was started in 1905 at the Bloemfontein Conference while others (quoted in Madise 2008, 117-126), such as Deborah Gaitskill (in Elphick and Davenport 1997, 253), state that the organisation was started in 1919 in Johannesburg.

\section{Women's participation in the life and mission of the church}

The call to follow Jesus has a fundamental objective: to participate in His mission. This mission is described through the imagery of fishing. Jesus was not the first to use such a metaphor (Costas 1979, 20). The Old Testament sees Yahweh as a fisherman. Thus, for example, Yahweh tells Egypt: 'I will put hooks in your jaws, and make the fish of your streams stick to your scales' (Ezekiel 29:4). He swears that He will do the same thing with Gog (Ezekiel 38:4). Yahweh makes people 'like the fish of the sea, like crawling things that have no ruler'. He brings all of them up with a hook, $\mathrm{He}$ drags them out with His net, and He gathers them in His seine (Habakkuk 1:14-15). These and other Old Testament passages use the imagery of fishing to describe God's judgement on the nations. They portray God as the mighty judge from whose 'hook' no fish, even big ones such as Egypt and Gog, can escape. The Essenes community at Qumran, which existed during the lifetime of Jesus and produced the now famous Dead Sea scrolls, kept the fishing metaphor alive from the Old Testament prophetic tradition. But whereas the prophets saw God as the fisherman who judges the fish of the sea, in Qumran this task was promised to the Messiah. 
It is necessary to go beyond the traditional interpretation of Jesus' fishing metaphor. Far from being a simple play on words and appropriate to the situation of the four Apostles, Jesus' promise was an affirmation of profound theological significance. He inverted the traditional understanding of this imagery. Rather than identifying it with God's judgement, He relates it to God's saving grace. In His great mercy, however, He was providing opportunity to every 'fish' to be rescued from those waters. Jesus had come for this purpose and He was calling the disciples to follow Him that He may turn them into 'fishers of men' (Bruce 1958, 92-102). This is reminiscent of the words of the fourth Gospel, 'For God sent the Son into the world, not to condemn the world, but that the world might be saved through Him. He who believes in Him is not condemned; he who does not believe is condemned already' (John 3:17-18a). It is also reminiscent of Jesus' priestly prayer recorded in the same Gospel: 'Father, the hour has come; glorify thy Son that the Son may glorify Thee, since Thou has given Him power over all flesh, to give eternal life to all whom Thou hast given Him. And this is eternal life, that they know Thee the only true God, and Jesus Christ whom Thou has sent...As Thou didst send Me into the world, so I have sent them into the world' (John17:1b-3,18; Costas 1979, 20).

To be incorporated into the new community is not only to be led to follow Jesus, but also to be enabled to become a channel of His grace. The promise to transform Simon, Andrew, John and James into 'fishermen' made implicit the continuation of Jesus' mission through the Apostles, and through those who would become disciples after them. For as Jesus had been sent as the channel by which God's saving grace was to be made available to the whole of mankind, so the disciples were themselves to become the channels through which God's message of grace would reach the ends of the earth. Nowhere does it say that they were to become instruments of God by themselves in the salvation of women and men. It was Jesus who would enable them to become fishers. Some would feel incompetent. Others would get 'cold feet' when the going got rough. Others would feel discouraged and would be tempted to give up in defeat and go back to their old trade. Jesus, however, would make it possible for them to continue (Costas 1979, 23).

What an extraordinary reminder for the church in traditional Christian lands during this last quarter of the 20th century! From a church assailed and tossed about by a defeatist inferiority complex, a church filled with guilt about its past shortcomings, discouraged by the seeming impotence of its present ministry, physically and psychologically tired, traumatised by the prospects of a substantial decrease in its future role in society and in the lives of its members, to this stagnant church $($ Costas 1979, 20) which appears to be retreating from the frontiers of history and entering into a new 'religious isolationism'. Jesus says: 'Follow me and I will make you become fishers of men.' The way out of the present crisis in the church does not lie in the church itself, in more relevant programmes, up-to-date methods and techniques, the efficiency and talent of its leadership or in a return to old patterns 
(Costas 1979, 20). Rather, the way out of the present situation lies in a renewed insertion into the mission of Jesus Christ. It lies in the disposition of the church to humble itself before Him, in its willingness to let Him take control of its life and ministry, to let Him set its agenda for mission and transform its members by His Spirit into effective vessels of His grace and in its willingness to allow women to also be called (Costas 1979, 20).

\section{Women empowerment in the ministry}

The empowerment of women has become a frequently cited goal of development interventions (Mosedale 2003) and, more often than not, it is a confusing concept. Different people use the word 'empowerment' to mean different things. However, there are four aspects which seem to be generally accepted in the literature on women's empowerment. There is also a significant body of literature discussing how women's empowerment should be undertaken that has been or might be evaluated, but there are still major difficulties in doing so (Haddad 2003; Kang 2004; Masenya 2004; Onwunta and August 2012). Furthermore, many projects and programmes which espouse the empowerment of women show little, if any, evidence of attempts to define what this means in their own contexts. Much is said and written about empowering women in church but concrete steps that ensure tangible results need to be elucidated. Instead, traditional development goals, such as better health or increased income, are cited as evidence of empowerment. In such cases it is not clear what is added by using the word 'empowerment'. To be empowered, one must have been disempowered (Mosedale 2003). It is relevant to speak of empowering women because, as a group, they are disempowered in relation to men in society and in church.

A third party can help with the creation of a conducive environment in which women can empower themselves. The old saying that one can take a horse to water but one cannot force it to drink, applies here. Agencies may be able to create conditions favourable to their empowerment, but they cannot make it happen if they do not participate in it (Mosedale 2003). Accordingly, to Mosedale's definitions of empowerment can be added the sense that people can make decisions on matters which are important in their lives and have the ability to carry them out. Reflections, analyses and actions are involved in this process, which may happen on an individual or collective level.

There is some evidence in the literature that while women's own struggles for empowerment have tended to be collective, empowerment-orientated development interventions often focus more on the level of the individual rather than on structural establishment. Empowerment should be viewed as an ongoing process rather than an end product that could be achieved within a specific time. One does not arrive at a stage of being empowered in some absolute sense. People are empowered, or 
disempowered, relative to others or, importantly, relative to themselves at a previous time (Mosedale 2003).

\section{Models of power}

Power is central in any societal relationship (Rowlands 1997). Rowlands (1997) identifies three models of power. There is power that is top down and often conditions those who are powerless to accept it as their God-sanctioned reality. In this situation, power is related to conflict because the powerful 'wins' and exercises power over the defeated. This type of power relates to one-on-one relationships and is prevalent in families and institutions under the control of one leader.

The second model of power is seen as the ability to deny, in this case, women from getting to the level of decision-making (Rowlands 1997). In this case leaders decide who gets what, when and how. It is regulatory in nature and is concerned with the rules and methods of legitimising and discrediting some voices. Often this type of power operates undetected and can easily become a norm and accepted practice (Rowlands 1997).

Longwe (in Rowlands 1997) gives five helpful tips to enhance empowerment:

a. The welfare 'degree' where the basic needs of those who are on the underside of history are met. This gesture does not temper with structural causes of disempowerment and tends to take advantage of the affected as passive recipients. In this case, those in power are acting out of arrogance and think that they know what the powerless need.

b. The access 'degree' where equal access to power and privileges are ensured.

c. The conscientisation and awareness raising 'degree' where structural issues affecting the powerless are discussed.

d. The participation and mobilisation 'degree' where structural and institutional discrimination and exclusion are addressed in a fundamental way.

e. The control 'degree' where equal decision-taking is established and recognised.

Armed with this kind of awareness and commitment, the MCSA should go a long way in not only empowering women within its midst, but also transforming the oppressive structures for the welfare of all and the advancement of God's Kingdom on earth.

The third model of power, according to Rowlands (1997), refers to a situation where the powerful succeed in making allies with the powerless by preventing dissent and yet not transcending the limitations imposed by the inequalities. Here the situation is manipulated to the extent that the powerless see the underlying conflict of 
interest. The oppressed come to a situation where they accept the legitimised wrong practices and live with them (Mosedale 2003).

Mosedale (2003) proposes ways of empowering people who find themselves in the three models of power stated above. She proposes what she calls a 'non zero model of power'. This includes 'power within', 'power to' and 'power with'.

a. 'Power within'. Oppressed and marginalised people may develop a syndrome where they internalise the feelings of their worthlessness and succumb to the manipulation of the powerful (Mosedale 2003). In such conditions, self-esteem, self-confidence and self-assertiveness may serve as effective empowerment tools. Although these forms of recognition and assertiveness are difficult to come by, they are the cognitive models that need to be exploited for the emancipation of women in church ministry.

b. 'Power to'. Mosedale uses the example of learning to illustrate this point. If a person gets involved in studies, such a person increases his or her level of skills without diminishing the skills of others. This approach creates new possibilities to the oppressed in such a way that the boundaries of the oppressed are increased without the threat of domination to the boundaries of the oppressor (Mosedale 2003).

c. 'Power with'. According to Rowlands (1997), this model of power refers to 'collective action'. Once people have realised that all humans have been created in the image of God and bestowed with God's power to be co-creative agents of His purposes on earth, equal opportunities can be created to empower all for the common purpose. Women should be given 'space' where they can develop themselves and be provided with role models to enhance their ability and creativity to break 'passivity in oppression' (Mosedale 2003).

All three models of women empowerment listed above should be set as measurable objectives. Women empowerment should be 'outcome based' (Mosedale 2003). Continuous assessments should be conducted in order to monitor the process of the empowerment of women and corrective actions should be employed where the objectives are not met. Evaluation should be made to determine why the outcome was or was not reached and new strategies should be designed to keep the process focused and effective.

\section{Transformation for inclusiveness of women in ministry}

Daszko, Sheinberg and Ravindran (in Kgatla 2013, 1-5) warn that transformation has become a buzzword that is both overused and misunderstood in today's world. Women hear the slogans of transformation in their churches, but they see no change in their lives. It is easy for church leaders to 'talk the language' and they may even try to take action in pursuit of what they understand to be transformation, but they 
often show no tangible benefits (Kgatla 2013, 5). In some circles, 'transformation talk' can become a mere catchphrase used to lull women into believing that those who use the language are indeed serious about their lot in the church. Transformation is a missional agenda of the church as dictated by the triune God as He changes the church according to His mission (Bosch 1991, 346). It is about asking and allowing God to transform the church and usher in His Kingdom and His rule that would negate human-designed 'kingdoms'.

The mission of God through the church to the world involves transformation that brings new hope, life and prosperity for all. Transformation involves a radical change (Kgatla 2013,8) that brings about new hope for all and change that involves pain that goes with uncertainties for those who are in privileged positions. It 'disempowers' those who were wrongly empowered and brings those who were 'disempowered' throughout history to their rightful position in the church. Transformation is a process of radical social change in which old dehumanising practices are replaced with 'purposive' strategic intervention with a view of creating a new community of God where Christ is the Lord.

Haddad (in Onwunta and August 2012) views transformation as a social change that is 'the heart of the mission of God to the world' where both men and women are 'restored' to full humanity (Commission of Mission and Evangelism 2013). Transformation, as empowerment, presupposes participation in mission, freedom, partnership with self-reliance, relationships and transparency, self-emptying and solidarity, accountability and responsibility, equality and justice, love, peace and dignity.

\section{Participation in mission and in solidarity}

Onwunta and August (2012) argue that God's mission through His church is participatory and in solidarity for both men and women. The participation of men and women on an equal basis in His mission is both empowering and transformative in its nature. In the mission of God, all participants should be aware of its nature, demands, obligations and social reality (Presbyterian Church USA 2003). In the participatory mission both sexes are equal and self-reliant; they feel that they are contributing in their own rights. It is only when both genders are engaged in true partnership in the mission of God that the historical divisions may be addressed and corrected.

Gender is part of what it means to be created in the image of God, and the skills, gifts and abilities of all should be valued, regardless of gender. It is an offence to God, and to many people in church and society (especially when men say that women are not ready to lead), to restrict women who feel called to serve in God's mission and in the ordained ministry of the church. Discrimination on the basis of gender does not enhance the mission of God or comment on it as good news (Neill 
and Anderson 1970, 44). According to Neill and Anderson: 'It does not glorify Jesus the Christ, but rather, is a stumbling block, a scandal made by some ill-informed men's decisions, not God's' $(1970,357)$. This goes to the heart of the Gospel.

\section{The Methodist ethos and rule of life}

For members of the MCSA, the spirit and practice of Christian love is an indispensable condition for membership. MCSA members are constantly urged to seek to be made perfect in love (The Methodist Book of Order 2014, 25). The standard set by the Apostles is the high vocation of the Methodist Church. It is thus incumbent on every member of the church to share his or her gifts wisely (The Methodist Book of Order 2014, 25). Methodist institutions such as the Class Meeting and the Connexion units are based on the assumption that all its members who love Jesus Christ, will love one another.

The Methodist Book of Order $(2014,25)$ argues that the Methodist rule of life is also based on the same foundation of Christian love. Members have 'social and ethical obligations and the sacrificial service for the Kingdom of God, to which those who confess Christ commit themselves after the example of their Lord and Master' (The Methodist Book of Order 2014, 25). The Methodist Rules, as drawn by Charles Wesley in 1743, still enforce the social responsibility in the spirit of fellowship to all people. 'Doing good and avoiding all harm of every kind, doing good by being merciful after one's power' are the pillars on which the life and mission of the church are built.

It is against this backdrop that the participation of women in the ministry was investigated, assessed and evaluated. Imperfect as the church might be, one would expect attempts from the side of male members in particular to be seriously engaged and one would expect a fierce struggle to eliminate any form of discrimination against women in the church. The law of love is the law of Christ for all His disciples and these should be guiding principles in the manner in which other members of the church are treated, regardless of impeaching cultural norms. 'Where two elephants were fighting there are traces of smothered grass,' as an African expression says.

Murphy $(2013,57)$ contests that Jesus had men and women followers who were His co-workers supporting His ministry. He did not raise the question of gender. His message of God's Kingdom 'extends loving acceptance to women and men alike' without regard for social standing, ethnicity or cultural background. Various gifts of believers expounded by Paul in Scripture are not based on gender preference. Apostle teaching, as is the case with Jesus' teaching, demands unquestionable and total surrender. Love and compassion overpower those who are involved in the ministry to empower and transform structures of death in mission (Murphy 2013, 61). Women who experience painful rejection by men or other women members and 
who are humiliated need a 'big hug' from church leadership and a sincere apology that the church will not leave things as they are (Murphy 2013, 61).

\section{Concluding summary}

The objectives of this study emanate from the MCSA ethos, rule of life and praxis of women ministry within the church ministry. The unconditional involvement of women in the mission of the MCSA is met with issues of integrity and biblical justice. Radical change is thus a prerequisite in the empowerment of women and transformation of structures that deny them life in its fullness (Mezirow 1997).

\section{LIST OF REFERENCES}

Attwell, A.F.I. 2005. The Methodist Church: An introduction. Cape Town: Methodist Publishing House.

Bosch, D.J. 1991. Transforming mission: Paradigm shifts in theology of mission. Maryknoll, NY: Orbis Books.

Brandel-Syrier, M. 1962. Black woman in search of God. London: Lutterworth.

Bruce, F.F. 1958. 'Qumran and the New Testament.' Faith and Thought, 90(2): 92-102.

Commission of Mission and Evangelism. 2013. Together towards life: Mission and evangelism in changing landscape. World Council of Churches Statement in Busan Southern Korea.

Costas, O.E. 1979. The integrity of mission: The inner life and outreach of the church and its mission. Orlando, FL: Data Costas.

Elphick, R. and R. Davenport. 1997. Christianity in South Africa: A political, social and cultural history. Los Angeles, CA: University of California.

Haddad, B. 2003. 'Gender development and faith: The church and women's struggle to survive.' Missionalia, 31(3): 427-450.

Hoch, C.B. 1987. 'The role of women in the church: A survey of current approaches.' Grace Theological Journal, 8(8): 240-250.

Hogan, M. 2002. 'Oppressed people suck,'. The Ethical Spectacle, August 2002. www.spectacle. org (accessed 20 October 2014).

Holness, L.J. 1990. Contextualising faith from the perspective of a South African woman. Unpublished M.Th dissertation. Unisa.

Holness, L.J. 1997. Women's piety and empowerment: An observer's understanding of the Methodist women's Manyano Movement. http://web.uct.ac.za/depts/risca/jtsa/j98-holn.htm (accessed 12 October 2014).

Kang, N. 2004. The centrality of gender justice in prophetic Christianity and the mission of the church reconsidered. NOTE Conference, South Africa 22-26 March 2004.

Kent, S. 1998. Gender in African prehistory. London. SAGE. 
Kgatla, S.T. 2013. The transformational, intersectional and transcendental agenda of mission: Quest for a spirituality of the road. In Association of Professor of Mission 2013. Wilmore, KY: First Fruits Press.

Madise, M.J.S. 2008. 'The Manyano movements within the Methodist Church of Southern Africa: An expression of freedom of worship.' Studia Historiae Ecclesiasticae, 34(2): 117-126.

Masenya, M. 2004. 'Teaching Western-oriented Old Testament studies to African students: An exercise in wisdom or in folly.' Old Testament Essays, 17(2): 455-469.

Masenya, M. 2012. 'Without a voice, with a violated body: Re-reading Judges 19 to challenge gender violence in sacred texts.' Missionalia, 40(3): 205-216.

Methodist Book of Order. 2014. The laws and discipline of the Methodist Church of Southern Africa. Bloemfontein: Methodist Publishing House.

Methodist Book of Records. 2014. Cape Town: Methodist Publishing House.

Methodist Year Book. 1999-2000. Cape Town: Methodist Publishing House.

Mezirow, J. 1997. 'Transforming learning: Theory to practice.' New Directions for Adult and Continuing Education, 1997(74): 5-12.

Minutes of Methodist Conferences. 1960. http://www.uah.es/biblioteca/documents/Harvard Guide-v3.o.2 (accessed 20 October 2013).

Minutes of Methodist Conferences. 1964. http://www.uah.es/biblioteca/documents/Harvard Guide-v3.o.2 (accessed 20 October 2013).

Minutes of Methodist Conferences. 1986. http://www.uah.es/biblioteca/documents/Harvard Guide-v3.o.2 (accessed 20 October 2013).

Minutes of Methodist Conferences. 1996. http://www.uah.es/biblioteca/documents/Harvard Guide-v3.o.2 (accessed 20 October 2013).

Mkhwanazi, F. 2002. Manyano organisations in the Methodist Church of Southern Africa. Unpublished MA dissertation. University of KwazuluNatal.

Mosedale, S. 2003. Towards a framework for assessing empowerment. Paper prepared for the international conference: New Directions in Impact Assessment for Development: Methods and Practice, Manchester UK.

Mudimeli, L.M. 2011. The impact of religious and cultural discourses on the leadership development of women in the ministry: A Vhusadzi (Womanhood) perspective. Published D.Th. thesis. University of South Africa.

Murphy, R. 2013. Women and men in ministry today. In Women and men in Scripture and church: A guideline to the key issues, S. Croft and P. Gooder (eds). Norwich: Canterbury.

Myers, B.L. 1999. Walking with the poor: Principles and practices of transformational development. Maryknoll, NY: Orbis books.

Neill, S. and R.S. Anderson. 1970. 'Call to mission.' Journal of Lutherans Ethics, Ordaining Women. Minneapolis, M.N: Fortress.

Oduyoye, M.A. 1980. The value of African religious beliefs and practices for Christian theology. In African Theology en route, Kofi, A.K and T. Sergio (eds), pp. 109-116. Maryknoll, NY: Orbis books.

Onwunta, U. and K.T. August. 2012. 'Gender partnership as a transforming paradigm for development in the Church and society’. HTS Theological Studies, 68 (2): 9. 
Oosthuizen, C.M. 1990. Conquerors through Christ: The Methodist deacons in South Africa. Port Shepstone: Reynolds.

Presbyterian Church USA. 2003. Presbyterian do mission in partnership. 2003 General Assembly policy statement.

Preston, S.D. 2007. A decision theory perspective on why women do or do not decide to have cancer screening. Jan Vol. 65(6).

Rakoma, J.R.D. 1971. Marema-ka-dika. Pretoria: Van Schaik.

Rowlands, J. 1997. Questioning empowerment: Working with women in Honduras. Oxfan: Oxford University Press.

Polgreen, L. 2012. 'South Africa debates law to support tribal courts.' The New York Times.com. http://www.nytimes.com/2012/06/17/world/africa/south-africa-looks-to-apply-tribal-law. html?_r=0 (accessed 10 February 2015).

Theilen, U. 2003. Gender, race, power and religion: Women in the Methodist Church of southern Africa in post-apartheid society. Unpublished $\mathrm{PhD}$ thesis. University of Marburg.

Walter, T. 1990. 'Why are most churchgoers women? A literature review.' Vox Evangelica, 20(1990): 73-90.

www.africanholocaust.net (accessed 10 February 2015). 